\title{
An estimate of the incidence and prevalence of laryngeal papillomatosis in São Paulo State (Brasil)
}

\author{
(iD) Gustavo Mercuri ${ }^{1}$ \\ (D) Sérgio Augusto Rodrigues ${ }^{2}$ \\ (D) Regina Helena Garcia Martins ${ }^{3}$
}

1. MD. Doutorando em Ciências da Cirurgia. Otorrinolaringologista e Médico Residente de Cirurgia de Cabeça e Pescoço. Departamento de Oftalmologia, Otorrinolaringologia e Cirurgia de Cabeça e Pescoço da Faculdade de Medicina de Botucatu, Universidade Estadual Paulista, São Paulo, Brasil. 2. PhD. Departamento de Bioestatística - Instituto de Biociências, Universidade Estadual Paulista, São Paulo, Brasil. 3. MD. PhD. Livre Docência. Otorrinolaringologista. Departamento de Oftalmologia, Otorrinolaringologia e Cirurgia de Cabeça e Pescoço da Faculdade de Medicina de Botucatu, Universidade Estadual Paulista, São Paulo, Brasil.

\section{SUMMARY}

BACKGROUND: Recurrent laryngeal papillomatosis, caused by the Human Papilloma Virus, has a significant economic impact worldwide and there are no epidemiological data of this disease in Brasil.

OBJECTIVE: The objective of the study was to estimate the incidence and prevalence of laryngeal papillomatosis of some otorhinolaryngology centers in São Paulo State (Brasil).

METHODS: A questionnaire containing data on the number of new and follow-up cases diagnosed with laryngeal papillomatosis was sent to the Otorhinolaryngology services ( $n=35)$ of São Paulo State (Brasil).

RESULTS: A total of 20 otorhinolaryngology centers answered the questionnaire. Of these, the five largest regional health centers were selected as follows: Campinas (42 cities - 4,536,657 inhabitants), Sao Jose do Rio Preto (102 cities - 1,602,845 inhabitants), Ribeirão Preto (26 cities - 1,483,715 inhabitants), Bauru (68 cities - 1,770,427 inhabitants), and Sorocaba (47 cities - 2,478,208 inhabitants). The incidence and prevalence of each regional health centers were, respectively: Campinas (5.51;7.27), Sorocaba (2.02;6.86), São José do Rio Preto (1.87;7.49), Ribeirão Preto (11.46;22.92), and Bauru (3.95;7.91).

CONCLUSION: The incidence and prevalence of the laryngeal papillomatosis of the five largest regional health centers of the interior of São Paulo State (Brasil) varied between 1.87 to 11.46 and 6.86 to 22.92 per 1,000,000 inhabitants, respectively for a total population of $11,871,852$ inhabitants

KEYWORDS: Papilloma. Larynx. Laryngeal neoplasms. Papillomaviridae. Epidemiology. Incidence. Prevalence.

\section{INTRODUCTION}

Laryngeal papillomatosis is the most common benign neoplasm caused by the Human Papillomavirus $(\mathrm{HPV})^{1,2}$. It is characterized by the presence of multiple proliferative and exophytic lesions of conjunctive tissues, covered by squamous epithelium, which happens especially in the anterior third of the vocal folds (figure 1). The disease course in children is more aggressive, undergoing several relapses and exposing

DATE OF SUBMISSION: 28-Feb-2020

DATE OF ACCEPTANCE: $15-$ Mar-2020

CORRESPONDING AUTHOR: Regina Helena Garcia Martins

Ophthalmology, Otorhinolaryngology and Head Neck Surgery Department, Botucatu Medical School

Univ. Estadual Paulista, Distrito de Rubião Junior, s/n, Botucatu, SP, Brasil - 18618-970

Tel: +55 14 3880-1523 / Fax: +55 14 3811-6256

E-mail: regina.g.martins@unesp.br 
the child to surgical interventions. The symptoms of permanent hoarseness can evolve to dyspnea and stridor, in more severe cases.

The pathways of contamination are not totally understood; however, sexual and vaginal transmission during pregnancy is discussed ${ }^{3-6}$.

The diagnostic and treatment costs of diseases caused by HPV present an important economic impact worldwide ${ }^{7}$. International data indicate that, in 2003, the United States spent US\$ 418 million in the treatment of diseases caused by HPV, while Italy spent 528,6 million Euros for the same treatment ${ }^{7}$. In Brasil, the lack of national epidemiological data regarding the incidence and prevalence of Recurrent Respiratory Papillomatosis (RRP) does not allow us to analyze the behavior of the disease in our population, as well as the benefit of preventive measures, like vaccination, available throughout the national territory in the past few years. Thus, this study aims to estimate the incidence and prevalence of Laryngeal Papillomatosis in some otolaryngology services in the interior of the São Paulo State.

\section{METHODS}

In Brasil, São Paulo health services are grouped into 16 health directories (https://www.ibge.gov.br/) ${ }^{8}$. After identifying each regional center and the number of cities in each of them for health care, the otolaryngology services were identified from the registered data in the Brazilian Association of Otolaryngology and Cervicofacial Surgery. From that point, a questionnaire was sent to the doctor responsible for the services of otolaryngology in these centers, containing questions regarding the number of new and follow-up

\section{FIGURE 1. PAPILOMATOSE LARINGEA}

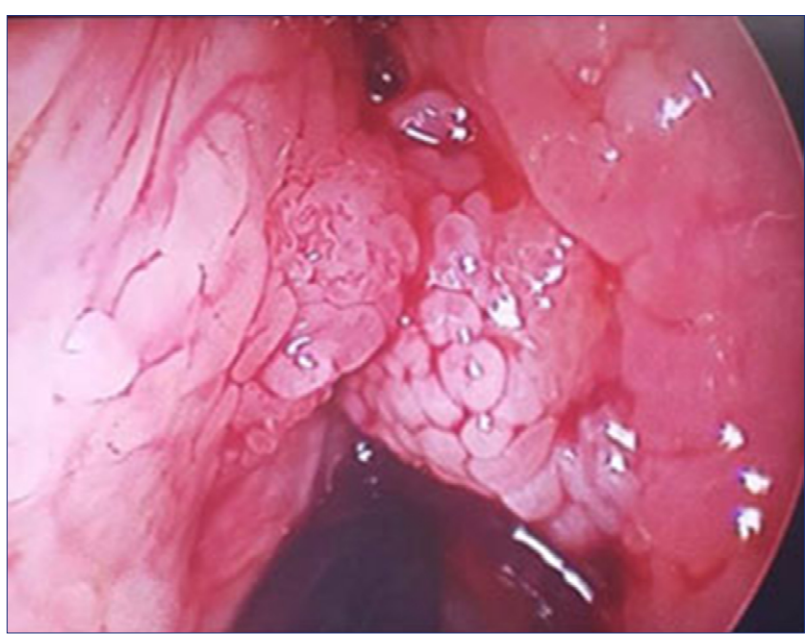

cases with laryngeal papillomatosis diagnostic which were cared for during 2017. The contacts were made through postage, email, phone, and personal contact.

\section{Minimum Incidence and Prevalence}

Minimum Incidence (I) of laryngeal papillomatosis by health region on the interior of the São Paulo State (table 1).

Data referring to the incidence of Laryngeal Papillomatosis in each health region were obtained through the following equation:

$$
I=\frac{X}{N} X 1.000 .000
$$

$\mathrm{X}$ - number of newly diagnosed cases of recurring laryngeal papillomatosis in 2017 in a determined health region in the São Paulo State.

$\mathrm{N}$ - total population of this evaluated health region.

Minimum Prevalence $(P)$ of recurrent laryngeal papillomatosis by health region of the interior of the state of São Paulo (table 1).

Data referring to the prevalence of Laryngeal Papillomatosis in each health region were obtained through the following equation:

$$
P=\frac{Y}{N} X 1.000 .000
$$

Y - Number of follow-up cases of recurrent laryngeal papillomatosis in 2017 in a specific health region of the interior of the São Paulo State.

$\mathrm{N}$ - total population of this evaluated health region.

The study was approved by the Research Ethics Committee of the Botucatu School of Medicine $\left(\mathrm{n}^{\circ}\right.$ 2.700.908) on 06/04/2018.

\section{RESULTS}

Among the 35 otorhinolaryngology services that received the questionnaire, only 20 returned them. The health regions belonging to these centers were selected, totalizing 285 cities, as follows: Campinas (42 cities - 4,536,657 inhabitants), Sao Jose do Rio Preto (102 cities - 1,602,845 inhabitants), Ribeirão Preto (26 cities - 1,483,715 inhabitants), Bauru (68 cities $-1,770,427$ inhabitants) and Sorocaba (47 cities $-2,478,208$ inhabitants) (Table 1).

Table 1 shows that the incidence and prevalence of laryngeal papillomatosis varied between 1.87 to 
11.46 and 6.86 to 22.92 , per 1,000,000 inhabitants. In Ribeirão Preto the incidence and prevalence were higher than in the other cities. Adults were more compromised.

\section{DISCUSSION}

In our study, the incidence and prevalence of laryngeal papillomatosis in the five largest regional health centers of the interior of the São Paulo State (Brasil) varied from 1.87 to 11.46 and 6.86 to 22.92 , per 1,000,000 inhabitants, respectively, for a total population of 11,871,852 habitants. Table 1 shows important variations between the health regions, with emphasis on the region of Ribeirão Preto, in which levels are three times higher than in the other regions. The literature does not have national data that allow us to analyze the regions comparatively. The lack of answers from the rest of the Otorhinolaryngological centers also impaired the scope of this study.

American estimates indicate that in the United States the incidence of laryngeal papillomatosis is near to 43 per 1,000,000 children aged 14 years or less $^{9}$. Another study pointed to lower levels of incidence and prevalence, respectively, for the city of Atlanta (11.1 and 25.9 per 1,000,000 inhabitants) and Seatle (3.6 and 16.9 per 1,000,000 inhabitants) ${ }^{\mathbf{1 0}}$. Campisi et al. ${ }^{11}$ performed a national survey of children and youngsters in Canada and noticed an incidence of papillomatosis of 2.4 per 1,000,000 and a prevalence of 11.1 per 1,000,000 inhabitants. In 2014, Marsico et al. ${ }^{12}$ published a longitudinal retrospective cohort study performed in the United States from data given by private and public insurers on the population aged from 0 to 17 years. The authors noticed an incidence of laryngeal papillomatosis, respectively for each insurer, of 5.1 and 10.3 per $1,000,000$ habitants, with a peak of incidence between the ages of 0-4 years, and a prevalence rate of 14.5 and 29.3 per 1,000,000 habitants, respectively. They also highlighted the higher levels in children with lower socioeconomic status. In a retrospective study that included 48 cases of laryngeal papillomatosis diagnosed in a period of ten years in Senegal, Maïga et al. ${ }^{13}$ registered 4.8 cases per year. As we have seen, the prevalence and incidence of papillomatosis vary greatly between regions and are influenced, probably, by different socioeconomic, cultural, and geographical conditions.

Laryngeal papillomatosis is a relatively rare disease in clinical practice, but with a high level of relapses and surgical interventions, which are exempt from sequelae to the laryngeal mucosa, with syneches and stenosis being the most terrible conditions, especially due to their predilection for the anterior portion of the glottis ${ }^{1,14-17}$.

To be sure, in the long term, of the benefits of the treatments being adopted, especially regarding vaccination campaigns, it is necessary to know the data relative to the behavior of the disease regarding its incidence and prevalence in our population, data which are practically non-existent.

Vaccines against HPV were introduced in the United States in 2006, initially recommended only for girls and young women, being posteriorly amplified to include boys and young men. Currently, vaccination is recommended for all children of 11 or 12 years, women and men of, at most, respectively, 26 and 21 years, with the costs being borne by private insurers and public programs. Even after so many years of availability of the vaccine, the levels of incidence and prevalence of laryngeal papillomatosis are still high in the United States. The rate of adhesion to vaccination against this disease is around $43.8 \%{ }^{\mathbf{1 8}}$.

TABLE 1. ESTIMATIVE OF INCIDENCE AND PREVALENCE OF LARYNGEAL PAPILLOMATOSIS IN HEALTH REGIONS OF LARGE CITIES OF THE SÃO PAULO STATE COUNTRYSIDE IN 2017, PER 1,000,000 INHABITANTS.

\begin{tabular}{l|l|l|l|l|l|l|l}
\hline Regional Health Centers & Population (Inhabitants) & \multicolumn{2}{|l|}{ Age range (in years) } & $\begin{array}{l}\text { New Cases } \\
(\mathbf{n})\end{array}$ & $\begin{array}{l}\text { Follow-up cases } \\
(\mathrm{n})\end{array}$ & Incidence & Prevalence \\
\hline & & $<20$ & $\geq 20$ & & & & \\
\hline Campinas & $4,536,657$ & 31 & 27 & 25 & 33 & 5.51 & 7.27 \\
\hline Sorocaba & $2,478,208$ & 5 & 17 & 5 & 17 & 2.02 & 6.86 \\
\hline Bauru & $1,770,427$ & 12 & 9 & 7 & 14 & 3.95 & 7.91 \\
\hline Ribeirão Preto & $1,483,715$ & 20 & 31 & 17 & 34 & 11.46 & 22.92 \\
\hline São José do Rio Preto & $1,602,845$ & 5 & 10 & 3 & 12 & 1.87 & 7.49 \\
\hline Total & $11,871,852$ & 73 & 94 & 57 & 110 & 4.80 & 9.27 \\
\hline
\end{tabular}

Source: IBGE (Brazilian Institute of Geography and Statistics) -20178 
In Brasil, vaccination was introduced in 2014, and it is indicated for girls between nine and 14 years and boys between 11 and 14 years. Unfortunately, we still do not have data in the literature that informs us of the number of children with laryngeal papillomatosis that have been forwarded to vaccination.

We believe that the initial epidemiological data presented in this study, which refers to a population of 11,871,852 habitants, totaling 285 cities of the São Paulo countryside, may guide future studies allowing the evaluation of the behavior of laryngeal papillomatosis in Brasil.

\section{CONCLUSION}

The incidence and prevalence of laryngeal papillomatosis in the five largest regional health centers of the interior of the São Paulo State (Brasil) varied from 1.87 to 11.46 and 6.86 to 22.92 per $1,000,000$ inhabitants, respectively, for a total population of $11,871,852$ habitants.

\section{Acknowledgments}

We would like to thank the otolaryngology services that participated in this study by answering the questionnaires.

\section{Author's Contribution}

Regina Helena Garcia Martins: study design, data analysis, paper writing, final manuscript review and approval.

Gustavo Mercuri: study design, data preparation, data compilation and analysis.

Sergio Augusto Rodrigues: statistical analysis, data analysis, final approval.

\section{RESUMO}

CONTEXTO: A papilomatose recorrente da laringe, causada pelo vírus do papiloma humano, tem um impacto econômico significativo em todo o mundo e não existem dados epidemiológicos dessa doença no Brasil.

OBJETIVO: O objetivo do estudo foi estimar a incidência e prevalência de papilomatose laríngea em alguns centros de otorrinolaringologia do estado de São Paulo (Brasil).

MÉTODOS: Um questionário contendo dados sobre o número de casos novos e de retornos diagnosticados com papilomatose laríngea foi enviado aos serviços de otorrinolaringologia (n-35) do estado de São Paulo (Brasil).

RESULTADOS: Vinte centros de otorrinolaringologia responderam ao questionário e, destes, os cinco maiores centros regionais de saúde foram selecionados da seguinte forma: Campinas (42 cidades - 4.536 .657 habitantes), São José do Rio Preto (102 cidades - 1.602 .845 habitantes), Ribeirão Preto (26 cidades - 1.483 .715 habitantes), Bauru (68 cidades - 1.770 .427 habitantes) e Sorocaba (47 cidades - 2.478 .208 habitantes). A incidência e prevalência de cada centro de saúde regional foram, respectivamente: Campinas (5,51; 7,27), Sorocaba (2,02; 6,86), São José do Rio Preto (1,87; 7,49), Ribeirão Preto (11,46; 22,92), Bauru (3,95; 7,91).

CONCLUSÃO: A incidência e prevalência da papilomatose laríngea dos cinco mais importantes centros regionais de saúde do interior do estado de São Paulo (Brasil) variaram entre 1,87 e 11,46 e 6,86 e 22,92, por 1.000.000 de habitantes, respectivamente, para uma população total de 11.871 .852 habitantes.

PALAVRAS-CHAVE: Papiloma. Laringe. Neoplasias laríngeas. Papillomaviridae. Epidemiologia. Incidência. Prevalência.

\section{REFERENCES}

1. Doyle JD, Gianoli JG, Espinola T, Miller RH. Recurrent respiratory papillomatosis: juvenile versus adult forms. Laryngoscope. 1994;104(5 Pt 1):523-7.

2. Carifi M, Napolitano D, Morandi M, Dall'Olio D. Recurrent respiratory papillomatosis: current and future perspectives. Ther Clin Risk Manag. 2015;11:731-8

3. Quick CA, Watts SL, Krzyzek RA, Faras Al. Relationship between condylomata and laryngeal papillomata. Clinical and molecular virological evidence. Ann Otol Rhinol Laryngol. 1980;89(5 Pt 1):467-71.

4. Gerein V, Soldatski IL, Babkina N, Onufrieva EK, Barysik N, Pfister H. Children and partners of patients with recurrent respiratory papillomatosis have no evidence of the disease during long-term observation. Int J Pediatr Otorhinolaryngol. 2006;70(12):2061-6.

5. Castellsagué $X$. Natural history and epidemiology of HPV infection and cervical cancer. Gynecol Oncol. 2008;110(3 Suppl 2):S4-7.
6. Skoczyński M, Goździcka-Józefiak A, Kwaśniewska A. Risk factors of the vertical transmission of human papilloma virus in newborns from singleton pregnancy - preliminary report. | Matern Fetal Neonatal Med. 2014,27(3):239-42.

7. Burger EA, Sy S, Nygård M, Kristiansen IS, Kim JJ. Prevention of HPV-related cancers in Norway: cost-effectiveness of expanding the HPV vaccination program to include pre-adolescent boys. PLoS One. 2014;9(3):e89974.

8. Instituto Brasileiro de Geografia e Estatística. Available from: https://www. ibge.gov.br

9. Hu D, Goldie S. The economic burden of noncervical human papillomavirus disease in the United States. Am J Obstet Gynecol. 2008;198(5):500.e1-7.

10. Armstrong LR, Preston El, Reichert M, Phillips DL, Nisenbaum R, Todd $N W$, et al. Incidence and prevalence of recurrent respiratory papillomatosis among children in Atlanta and Seattle. Clin Infect Dis. 2000;31(1):107-9. 
11. Campisi P, Hawkes M, Simpson K; Canadian Juvenile Onset Recurrent Respiratory Papillomatosis Working Group. The epidemiology of juvenile onset recurrent respiratory papillomatosis derived from a population level national database. Laryngoscope. 2010;120(6):1233-45.

12. Marsico M, Mehta V, Chastek B, Liaw KL, Derkay C. Estimating the incidence and prevalence of juvenile-onset recurrent respiratory papillomatosis in publicly and privately insured claims databases in the United States. Sex Transm Dis. 2014;41(5):300-5.

13. Maïga S, Ndiaye C, Diouf M, Diallo BK, Ndiaye M, Diouf MS, et al. Laryngeal papillomatosis in Senegal: a ten-year experience. Eur Ann Otorhinolaryngol Head Neck Dis. 2018;135(3):221-4.

14. Bostrom B, Sidman J, Marker S, Lander T, Drehner D. Gefitinib therapy for life-threatening laryngeal papillomatosis. Arch Otolaryngol Head Neck Surg. 2005;131(1):64-7.
15. Fortes HR, von Ranke FM, Escuissato DL, Araujo Neto CA, Zanetti G, Hochhegger $B$, et al. Recurrent respiratory papillomatosis: a state-of-the-art review. Respir Med. 2017;126:116-21.

16. Benedict PA, Ruiz R, Yoo M, Verma A, Ahmed OH, Wang B, et al. Laryngeal distribution of recurrent respiratory papillomatosis in a previously untreated cohort. Laryngoscope. 2018;128(1):138-43.

17. James M, Katundu D, Chussi D, Shija P. Prevalence, clinical presentations, associated risk factors and recurrence of laryngeal papillomatosis among inpatients attended at a Tertiary Hospital in Northern zone Tanzania. Pan Afr Med J. 2018;30:209

18. Yiu Y, Fayson S, Smith H, Matrka L. Implementation of routine HPV vaccination in the management of recurrent respiratory papillomatosis. Ann Otol Rhinol Laryngol. 2019;128(4):309-15. 